\title{
Review
}

\section{Radical enfranchisement in the jury room and public life}

\author{
Sonali Chakravarti \\ University of Chicago Press, Chicago, 2019, 148pp., ISBN: 978-0-226- \\ 65429-4
}

Contemporary Political Theory (2021) 20, S188-S191. https://doi.org/10.1057/s41296020-00452-y; published online 19 October 2020

In Radical Enfranchisement in the Jury Room and Public Life, Sonali Chakravarti argues that the jury is an important, if often overlooked, democratic space. From the outset, the author recognizes that in contemporary legal practice, few cases go to jury trial. But for Chakravarti, that something is 'fleeting and rare' (p. 2) in democratic life is no reason to disregard its potential significance. Citizens' role as jurors, she suggests, might foster their 'best democratic instincts' (p. 29) - might, because Chakravarti acknowledges how the institution as it currently exists would have to be radically transformed to make this so. Her book is best understood as an argument for, if not a roadmap to, that transformation. Where popular conceptions of jury service represent it as a burden, Chakravarti argues we might instead see jury duty as the 'defining act of democracy' (p. 100): citizens deliberating among themselves about the proper relationship between justice, law, and punishment. If political theorists see legislative self-authorship as a democratic ideal, they have overlooked a primary site of that ideal's presence in the lives of ordinary citizens.

Ordinary citizens' ability to serve as a check on the calcified and routine way court officers approach matters of punishment is the subject of chapter one. Placing Tocqueville's remarks on the independence of American women alongside his reflections on the jury as a schoolhouse of democracy, Chakravarti persuasively shows how Tocqueville's understanding of both groups as politically immature shapes his ultimately aristocratic ideal of juries. In contrast to Tocqueville's 'schoolhouse model' (p. 26) of the jury, Chakravarti's vision of radically enfranchised jurors would treat them, and women, as mature. They would be given the opportunity to diverge from court officers, in the former case, and their families, on the other.

The second chapter considers the hung jury as an example of that kind of divergence. Drawing on features of Jürgen Habermas' ideal speech situation, Chakravarti argues that the hung jury should not be seen as 'a mistake or inefficiency' (p. 59) in the judicial system. Instead, she suggests we understand the

(C) 2020 Springer Nature Limited. 1470-8914 Contemporary Political Theory Vol. 20, S4, S188-S191 
hung jury as a critical and democratic kind of interruption, when juries can be a 'hand brake on the punishment component of the criminal justice system' (p. 59). The jury's ability to interrupt is especially important for thinking about its role in light of contemporary problems of mass incarceration and racial bias in law enforcement that drive the book. While Chakravarti's treatments of Tocqueville and Habermas are judicious and sophisticated in their own right, they feel disjointed from the political analysis of juries' role in public life that is central to her argument.

In chapter three, Chakravarti turns her attention to the problem of bias, anxieties about which inevitably rise when decisions about punishment are placed in the hands of ordinary people. 'There is perhaps no more potent critique of the jury system' today, Chakravarti writes, 'than its complicity in a racist institution, one in which the inferior, often violent, treatment given to African-Americans and others is systemic' (p. 62). Chakravarti is keenly attuned to hesitations progressives may have about the role of juries in sedimenting, rather than upending, racist forms of injustice. She makes reference to the jury trials of George Zimmerman (who killed Trayvon Martin) and Rodney King throughout the first two chapters, but racial justice only becomes a central concern in chapter three.

Debates about the reasonable doubt standard, the subject of that chapter, often center on its application by jurors to the evidence presented to them at trial. Chakravarti's argument here is that jurors ought also to apply the standard to their own perceptions. The practice of turning reasonable doubt 'inwards' may, Chakravarti notes, 'bolster the types of effects scholars have claimed from racially diverse juries' (p. 70) and so further the desirable goal of reducing racial bias in judgments about guilt and punishment. While I appreciate that the phenomenology of 'destabilization' (p. 63), which she describes, is crucial for reducing bias in judgment, I would have liked to see this chapter also deal with the process of jury selection, which is itself ridden with bias and has drastic consequences for juries' democratic potential. The many barriers that exist to being a juror in the first place, such as the lack of paid leave granted to jurors in most states, are given sparse attention in the book and would bolster its enfranchisement thesis.

The orientation of radical enfranchisement, which Chakravarti suggests would be desirable for jurors in the jury room and public life, has implications for pressing conversations about mass incarceration, carceral abolition, and racial bias in the courtroom and democratic society today. Chakravarti's proposals for institutional reform are articulated most clearly and forcefully in chapter four. A lot rides on this chapter. Chakravarti considers a question of critical importance to both radical critics of the state and defenders of its legitimacy. Can and ought jurors' verdicts on the evidence in a particular case carry through to a broader or separate verdict on the legitimacy of the law being applied in the case at hand? Chakravarti's discussion of nullification, this 'secret power' (p. 81) of the jury, is especially important to the overall argument of the book. If juries can and should be made

(C) 2020 Springer Nature Limited. 1470-8914 Contemporary Political Theory Vol. 20, S4, S188-S191 S189 
more aware of the option of nullification, what implications would this carry for the legitimacy of the law? This chapter's argument will be of particular interest to scholars working on republican theories of participation and agonistic democracy.

If radical enfranchisement as an orientation asks of jurors that they practice skills of deliberation and self-assessment and learn to exhibit the maturity and courage required to stand in an adversarial relationship to officers of the court, jury nullification encompasses each of these aspects. The 'potency of nullification', Chakravarti writes, 'comes in the intersection of politics and the law', and null verdicts may have the power to 'draw attention to an urgent issue or an exceptional case' (pp. 94-95) in a way that guilty verdicts or acquittals do not. This chapter brings readers to the element of radical enfranchisement that pertains to public life, which remains underdeveloped in the first half of the book, itself largely focused on dynamics internal to the courtroom. While it is a public institution, it is often shrouded in secrecy (as Chakravarti shows) or otherwise impenetrable to ordinary citizens who avoid it. The last two chapters contribute to democratic theory by examining jurors' potential role in making particular legal cases public.

In the last chapter, Chakravarti responds to critics of her proposals that see jurors' radical enfranchisement as an instance of overreach, as well as to critics on the left who would want to distance themselves from the institutions of punishment altogether. The book ends with a quote from Emma Goldman, the anarchist whose critique of the United States prison system led her to conclude that, pending an awakening of social conscience, 'the average individual may learn to refuse the "honor" of being the bloodhound of the law' (cited on p. 116).

The thesis put forward in Radical Enfranchisement is that the costs of injustice are too great for citizens to opt out of their duties to judge. If citizens' role as jurors is properly cultivated through civic education about bias and the power of nullification prior to jury service, Chakravarti argues, they might not only refuse to be the bloodhounds of the law, but further serve as a powerful check 'against the tyranny of the state' and 'against the tyranny of police officers' (p. 112).

Absent an analysis of the process of jury selection and critical evaluation of sentencing guidelines, however, this book may not succeed in swaying its abolitionist critics. Still, it is an important and philosophically rigorous treatment of political-theoretical concepts of importance to scholars of liberal democracy. Its contributions to the scholarly literature on law and democratic deliberation are many, but the concerns about racial and gender inequity in public life that make this book so relevant remain underdeveloped.

In particular, a more explicit connection could be drawn between the argument about political maturity and democratic judgment in chapter one to the questions of bias raised in chapter three. How do race and gender contribute to the specter of political immaturity that haunts elites' suspicions of ordinary people's ability to make judgments about punishment? What would it look like to make jury duty an accessible democratic activity, and jurors more representative of the population? If 
it gestures to but does not answer these questions, Chakravarti's book will nevertheless be of great value to scholars thinking critically about the place of law and punishment in democratic societies beset by racial and gender inequities.

Publisher's Note Springer Nature remains neutral with regard to jurisdictional claims in published maps and institutional affiliations.

Agatha A. Slupek

University of Chicago, Chicago, IL 60637, USA aaslupek@uchicago.edu 